\title{
Metabolic State, Pancreatic Insulin Content and B-Cell Morphology of Normoglycemic Spiny Mice (Acomys cahirinus): Indications for an Impairment of Insulin Secretion*
}

\author{
W. Stauffacher, L. Orot, M. Amherdt, I.M. Burr, L. Balant, E. R. Froesch and A. E. Renotd
}

Division of Clinical Biochemistry of the Dəpartment of Medicine, Department of Histology of the University of Geneva, Switzerland, and Metabolic Unit, Department of Medicine of the University of Zurich Switzerland.

Summary. Plasma glucose, plasma IRI and pancreatic IRI content were measured and B-cell morphology was studied in fasted, fed and glucose-injected normoglycemic spiny mice of varying ages. Both high and low plasma IRI concentrations were observed at all ages, irrespective of the degree of pancreatic stimulation. In old but not in young animals, plasma IRI concentrations correlated with body weight, suggesting that accelerated weight gain was secondary to hyperinsulinemia. Pancreatic IRI content was higher than in other strains of non-diabetic mice and increased with age but was unrelated to either plasma IRI concentrations, or to body weight individual age groups. Relative to pancreatic IRI content, plasma IRI concentrations of spiny mice were lower than those of normal or obese-hyperglycemic mice of other strains. The B-cells showed an unusual degree of granulation. Pale granules predominated and had a characteristic tendency to fusion and confluence. With the exception of 1 out of 200 animals (in the islets of which emiocytosis was seen), no signs of enhanced insulin release could be observed. Neo-formation of $\beta$-granules by the Golgi complex of already well granulated cells was the only feature consistently associated with pancreatic stimulation by glucose injection. The data are in agreement with the hypothesis of a B-cell defect resulting in an impairment of insulin secretion and also suggest that the B-cells of normoglycemic spiny mice may contain two compartments of insulin: one which is accessible to secretory stimulation and has a rapid turnover and one which is relatively inaccessible to stimulation and accumulates with age. Available data do not allow for the identification of the postulated defect or for the anatomical or physiological definition of the two compartments of insulin.

Etat métabolique, contenu pancréatique en insuline et aspect morphologique des cellules $B$ de la souris à piquants (Acomys cahirinus) normoglycémique: Possibilité d'une altération de la sécrétion de l'insuline

Résumé. En mesurant les taux plasmatiques de glucose et de l'insuline immunoréactive (IRI), le contenu pancréatique en IRI, et en étudiant à l'aide du microscope électronique les pancréas de souris à piquants normoglycémiques à jeun, nourries ou après injection intrapéritonéale de glucose, les résultats suivants ont été obtenus: sans tenir compte du degré de stimulation pancréatique, les animaux des différents groupes d'âge ont pu être classés en deux catégories, soit ceux ayant une concentration basse ou élevée d'IRI plasmatique. Le fait qu'une corrélation entre le poids corporel et la concentration on IRI plasmatique peut être établie chez les animaux adultes, mais non pas chez les jeunes, indique que l'augmentation du poids corporel est plutôt la conséquence que la cause de l'hyperinsulinémie. Par rapport à d'autres espèces de souris normales ou hyperglycémiques, le contenu pancréatique en insuline des souris à piquants était élevé et augmenta progressivement avec

* Supported by the Fonds National Suisse de la Recherche Scientifique (Grants No. 4848.3 and 3.154.69). l'âge. Aucune corrélation n'a pu être établie entre les taux d'insuline plasmatique et pancréatique. Par rapport au. contenu pancréatique, les concentrations plasmatiques en IRI étaient plus bassses que celles d'autres souris normoglycémiques ou obèses-hyperglycémiques. Les cellules $B$ de souris à piquants montrent un degré très élevé de granulation. La plupart des granules $\beta$ sont du type pâle et ont une tendance à la fusion et à la confluence. A l'exception d'un animal sur 200, aucun signe morphologique de sécrétion active d'insuline n'a été observé ni chez les animaux nourris ni après stimulation par le glucose. Par contre, l'injection du glucose était suivie de néoformation de granules $\beta$ dans le complexe de Golgi de cellules déjà fortement granulées. - En se basant sur ces résultats, les auteurs postulent l'existence de deux compartiments à insuline dans les cellules $\mathrm{B}$ de la souris à piquants normoglycémique. L'un de ces compartiments - quantitativement peu important - serait accessible à la stimulation par le glucose et serait caractérisé par un taux élevé de renouvellement. Le deuxième - quantitativement plus important - serait relativement inaccessible aux stimuli physiologiques et augmenterait avec l'âge. Les résultats obtenus jusqu'ici ne permettent ni la définition fonctionnelle ni anatomique de ces deux compartiments.

Stoffwechsel, Insulingehalt des Pankreas und Morphologie der B-Zellen normoglykämischer Stachelmäuse (Acomys cahirinus): Hinweise auf eine Störung der Insulinsekretion

Zusammenfassung. Die Bestimmung von Plasma Glukose, Plasma immunoreaktivem Insulin (IRI) und Pankreas-IRI sowie die elektronenmikroskopische Untersuchung der Pankreata normoglykämischer Stachelmäuse im Nüchternzustand, nach Fütterung oder nach intraperitonealer Injektion von Glucose haben folgende Resultate ergeben: Unabhängig vom Stimulationsgrad des Pankreas ließen sich die Tiere aller Altersklassen in zwei Gruppen mit niedriger oder hoher Plasma-IRI-Konzentration aufteilen. Die Tatsache, daß Körpergewicht und Plasma-IRI-Konzentration bei älteren, nicht aber bei jungen Tieren miteinander korrelierten weist darauf hin, daß beschleunigte Gewichtszunahme eher die Konsequenz als die Ursache der relativ erhöhten Insulinkonzenzentrationen war. Der Insulingehalt des Pankreas aller Tiere war gegenüber demjenigen anderer nicht diabetischer Laboratoriumstiere erhöht und stieg mit zunehmendem Alter an. Es bestand keine Korrelation zwischen Plasma Insulin Konzentration und dem Insulingehalt des Pankreas. Im Verhältnis zum letzteren war die Insulinkonzentration im Plasma aller Tiere niedriger als die anderer normaler oder gar obes-hyperglykämischer Laboratoriumstiere. Die B-Zellen des Pankreas sämtlicher Tiere enthielten ungewöhnlich viele $\beta$-Granula. Bei der Mehrzahl der letzteren handelte es sich um sogenannte, ,helle“ Granula, die zudem eine charakteristische Tendenz zur Fusion und Konfluenz aufwiesen. Mit Ausnahme eines einzigen Tieres (von 200) konnten auch nach GlucoseStimulation keine morphologischen Hinwoise auf aktive Insulinsekretion festgestellt worden. Dagegen war im Golgi-Komplex der bereits stark granulierten Zellen regelmäßig Neubildung von $\beta$-Granula festzustellen. Aufgrund 
der erhobenen Befunde wird postuliert, daß die B-Zellen normoglykämischer Stachelmäuse zwei Insulinpools enthalten, von denen der kleinere auf Glucose-Stimulation reagiert und eine hohe Umsatzrate hat, wogegen der zweite und quantitativ bedeutendere, auf normale Stimulation nicht oder nur wenig anspricht und mit steigendem Alter zunimmt. Aufgrund der bisher vorliegenden Resul- tate können diese Pools weder funktionell noch anatomisch definiert werden.

Key-wards: Spiny mice, Acomys cahirinus, pancreas, IRI, insulin secretion, B-cell hyperplasia, pale $\beta$-granules, granule-fusion, two insulins, insulin biosynthesis, spontaneous diabetes, electronmicroscopy.
In previous reports concerned with the definition of the diabetic state of spiny mice $[5,6,16,8,9]$ it was observed that even the animals considered to be "normal" had elevated serum insulin concentrations and high pancreatic insulin content $[8,9]$. In addition, studies with light and electron microscopy had revealed uniform, apparently congenital hyperplasia of the islets of Langerhans in all animals, whether diabetic or not. In view of the small number of nondiabetic animals on which these observations had been made it was considered important to extend these studies in order to assess more reliably the incidence of hyperinsulinemia and of B-cell hyperplasia in normoglycemic spiny mice and to define an eventual relationship between the two features.

The present report summarizes the results of a vertical study of the normoglycemic population of our colony. Measurements of plasma glucose, plasma immunoreactive insulin (IRI) and of pancreatic IRI content were performed both in the basal state and after the injection of glucose using representative groups of animals aged between 1 and approximately 40 months. In addition, the effect of food restriction on pancreatic IRI content was examined. Electron microscopic studies were performed on the pancreases of all animals.

\section{Materials and Methods}

Animals. The conditions under which the colony is held have been described previously $[6,16,9]$. Body weights were recorded weekly and 24 -h urine collections obtained periodically as detailed elsewhere [9]. Most animals of our colony show trace-glycosuria in the fed state at the age of approximately 12 months. No metabolic or morphological differences were observed betwenn in animals which had shown such trace-glycosuria on one or two occasions and in those which had consistently been non-glycosuric. All animals included in the present study were non-glycosuric and normoglycemic in the fasting state. A group of animals, randomly selected at the time of weaning, was maintained on reduced food intake and received $2.5 \mathrm{~g}$ of laboratory chow per day (Altromin-R, Kunath, Aarau, Switzerland) without any supplement.

Experimental procedures. Animals to be studied in the basal state were weighed and put into metabolic cages $24 \mathrm{~h}$ before killing. During that time they were either normally fed or had access to water only. Animals to be injected with glucose were fasted for $24 \mathrm{~h}$ before the beginning of the experiment. They were injected intraperitoneally with $1 \mathrm{~g}$ of glucose per $\mathrm{kg}$ body weight (10\% sterile glucose solution). Since the small blood volume of spiny mice did not allow for serial measurements of plasma glucose and IRI concentrations and since it was intended to study B-cell morphology under stimulation with hyperglycemia, groups of 6 animals were killed at the time intervals indicated. They were anesthetized with Nembutal 30 min prior to killing. Therefore, animals killed up to 30 min after the injection of glucose received the injection while already under anesthesia. Killing was performed by bleeding from the throat after cutting with a razor blade.

Experimental samples. Blood was collected in heparinized microfuge tubes. After separation by centrifugation, plasma was divided into two samples for the measurement of glucose and IRI and stored at $-20^{\circ} \mathrm{C}$ until the time of assay. Pancreases were immediately dissected free of fat, weighed on a torsion balance and a small piece was removed for electron microscopy. The remainder was extracted in acid ethanol [18], and stored at $-20^{\circ} \mathrm{C}$ until the time of assay.

Analytical methods. Plasma glucose was measured by a micromethod using 0-toluidine [12], plasma IRI according to the modification of the method of Hales and Randle [7] described elsewhere [20]. Rat insulin was used as a standard throughout [9]. Where indicated, insulin like activity (ILA) of pancreatic extracts was measured using rat adipose tissue [11].

Samples for electron microscopy. Small blocks of pancreas were immediately fixed in ice cold $4 \%$ glutaraldehyde, buffered with phosphate [13] and postfixed in $2 \%$ Osmium-tetroxide, dehydrated with alcohol and embedded in Epon [11]. Semi-thin sections were cut in order to identify the islets of Langerhans and contiguous thin sections were cut with the LKB ultramicrotome, treated with lead hydroxide [10] and examined with a Philips 300 or a Zeiss-EM 9 electron microscope.

\section{Results}

\section{A. Metabolic Studies}

Table 1 summarizes the biological data obtained with animals killed at the ages indicated, including the data obtained with the two groups of animals held on reduced food intake. Plasma glucose concentrations were within the normal range and tended to be higher 
in young than in old animals. Plasma insulin concentrations varied considerably both within and besween the age groups studied. Pancreatic insulin content of young animals was high in comparison to that of nondiabetic mice of other strains or of rats and comparable to what we have previously observed in adult $o b o b$ mice [7]. In animals killed between 12 and 36 months, pancreatic insulin content increased progressively with age both per unit wet weight of pancreas and per whole

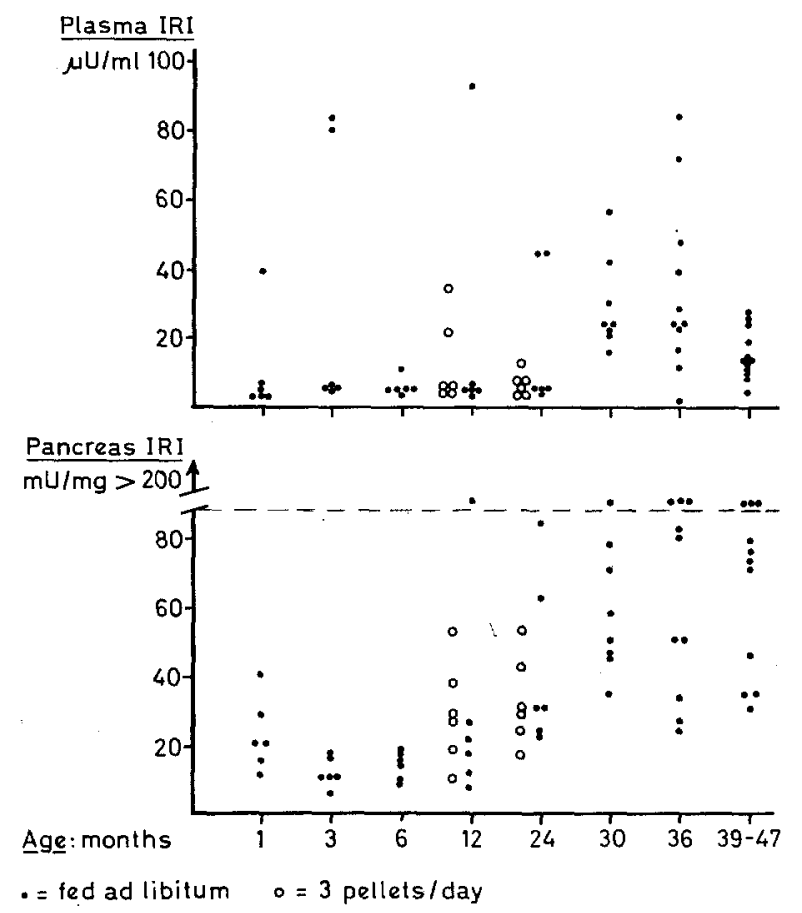

Fig. 1. Scattergram of individual values of plasma IRI concentration $(\mu \mathrm{U} / \mathrm{ml})$ and pancreatic IRI content $(\mathrm{mU} / \mathrm{mg})$ used for the calculation of means given in Table 1. Circles indicate animals maintained on reduced food intake. All animals were fasted
Fig. 1 represents a scattergram of the individual values for plasma IRI and pancreatic IRI content from which the means indicated in Table 1 were calculated. It shows that each age group included one or several animals with high fasting plasma IRI concentrations. In the groups killed up to the age of 6 months, the values of the remaining animals were rather low. In older animals, a progressive spread occurred, with the exception of the oldest animals which showed plasma insulin concentrations within the "normal" range. Pancreatic insulin content increased with age, in that both the lowest and the highest results obtained in old animals were higher than the corresponding values of the young age groups. Reduced caloric intake did not

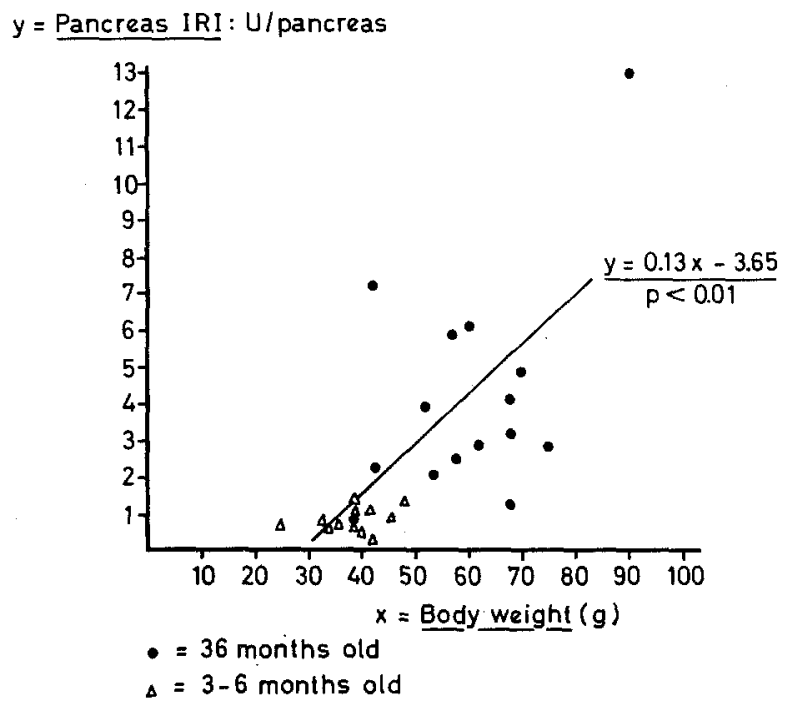

Fig. 2. Correlation between pancreatic IRI content (U/pancreas) and body weight (g) of 3 to 6 months old (triangles) and 36 months old (dots) normoglycemic spiny mice. The regression line was calculated on the basis of the pooled data from both age-groups

Table 1. Summary of biological characieristics of different age groups ${ }^{\mathbf{a}}$

\begin{tabular}{|c|c|c|c|c|c|c|}
\hline $\begin{array}{l}\text { Age } \\
\text { months }\end{array}$ & $\begin{array}{l}\text { Number of } \\
\text { animals }\end{array}$ & $\begin{array}{l}\text { Body weight } \\
\mathrm{g}\end{array}$ & $\begin{array}{l}\text { Plasma glucose } \\
\mathrm{mg} / 100 \mathrm{ml}\end{array}$ & $\begin{array}{l}\text { Plasma TRI } \\
\mu \mathrm{U} / \mathrm{ml}\end{array}$ & $\begin{array}{l}\text { Pancreas IRI } \\
\mathrm{mU} / \mathrm{mg}\end{array}$ & U/pancreas \\
\hline 1 & 6 & $26 \pm 1.6$ & $90 \pm 6.5$ & $10 \pm 6.0$ & $22.6 \pm 4.3$ & $0.74 \pm 0.12$ \\
\hline 3 & 6 & $36 \pm 2.4$ & $118 \pm 7.4$ & $31 \pm 16.2$ & $11.9 \pm 1.8$ & $0.81 \pm 0.16$ \\
\hline 6 & 6 & $41 \pm 2.2$ & $98 \pm 4.1$ & $6 \bar{I} 1.1$ & $13.8 \pm 1.7$ & $0.93 \pm 0.12$ \\
\hline $10^{\mathrm{b}}$ & 6 & $45 \pm 2.2$ & $119 \pm 11.2$ & $13 \pm 5.2$ & $29.7 \pm 6.6$ & $1.43 \pm 0.34$ \\
\hline 12 & 6 & $53 \pm 4.5$ & $113 \pm 7.0$ & $20 \pm 15.0$ & $37.9 \pm 21.0$ & $2.46 \pm 1.44$ \\
\hline $20^{b}$ & 6 & $44 \pm 1.8$ & $120 \pm 7.0$ & $7 \pm 1.4$ & $32.5 \pm 5.1$ & $2.41 \pm 0.32$ \\
\hline 24 & 6 & $65 \pm 5.6$ & $112 \pm 9.5$ & $19 \pm 8.3$ & $42.8 \pm 10.1$ & $3.40 \pm 0.69$ \\
\hline 30 & 8 & $67 \pm 5.1$ & $91 \pm 6.2$ & $29 \pm 4.2$ & $61.7 \pm 8.8$ & $4.43 \pm 0.69$ \\
\hline 36 & 14 & $60 \pm 5.2$ & $81 \pm 5.3$ & $24 \pm 4.6$ & $74.8 \pm 15.7$ & $4.23 \pm 0.79$ \\
\hline $39-47$ & 11 & $56 \pm 4.0$ & $69 \pm 4.8$ & $16 \pm 2.0$ & $75.8 \pm 12.1$ & $5.28 \pm 1.05$ \\
\hline
\end{tabular}

a All animals were in the fasting state. Results indicated are means \pm SEM.

b Animals on restricted food intake (see text).

pancreas. The results obtained with pancreases of animals on reduced food intake were similar to those found in animals on a normal diet and of comparable age. appear to affect pancreatic insulin content (circles). Thus, while both mean plasma and pancreatic insulin concentrations tended to be higher in older animals, high plasma insulin concentrations were already ob- 
served in a few very young animals. Grossly increased pancreatic IRI content, however, occurred only in the older age groups. Attempts to correlate individual fasting plasma IRI concentrations with pancreatic

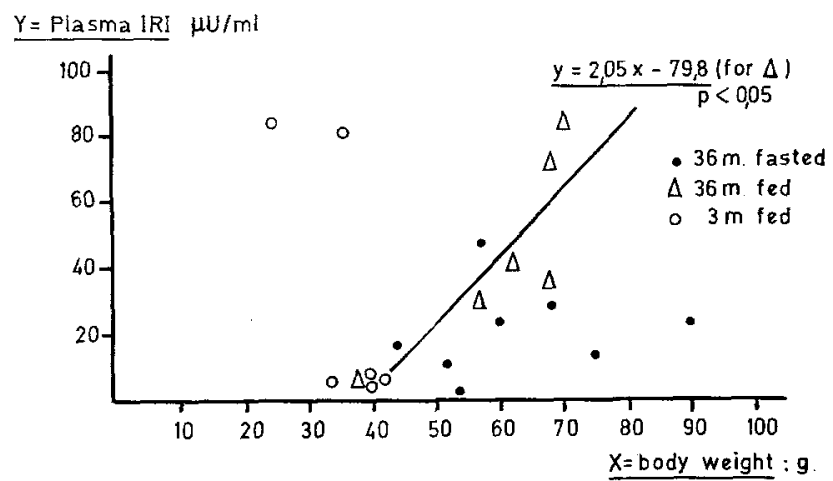

Fig. 3. Correlation between plasma IRI concentration $(\mu \mathrm{U} / \mathrm{ml})$ and body weight (g) of fasted (dots) and fed (triangles) 36 months old, and fed 3 months old (circles) normoglycemic spiny mice. The regression line was calculated from the values for fed 36 months old animals
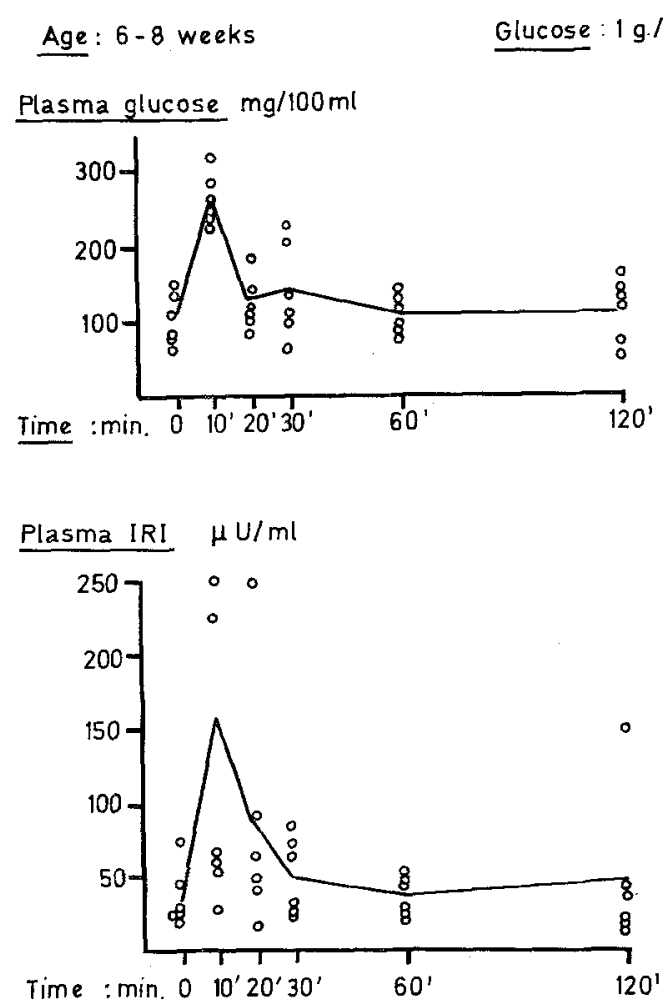

Fig. 4. Plasma glucose $(\mathrm{mg} / 100 \mathrm{ml}$, top panel) and plasma IRI concentrations ( $\mu \mathrm{U} / \mathrm{ml}$, bottom panel) of 6 to 8 weeks old normoglycemic spiny mice after the intraperitoneal injection of glucose ( $1 \mathrm{~g} / \mathrm{kg}$ body weight). Circles represent individual values. For details see text

insulin content or with body weight were unsuccessful. However, as indicated in Fig. 2, a significant correlation between pancreatic insulin content and body weight was found when both young (triangles) and old (dots) animals were considered together but not when the two age groups were considered apart.

In view of the apparent lack of correlation between fasting plasma insulin concentrations on the one hand, and plasma glucose, pancreatic insulin content or body weight on the other, a preliminary experiment was performed with fed young and old animals in order to determine whether plasma IRI concentrations measured in the fed state might correlate better with pancreatic insulin content or body weight. The results (Fig. 3) indicated that higher plasma IRI concentrations were associated with higher body weight in adult animals (triangles) but not in young ones (circles). With the latter, the highest value was measured in the lightest animal. Again, plasma insulin concentrations could not be related to pancreatic content (data not shown).

In an attempt to exclude the possibility that the high plasma insulin concentrations measured in relatively few animals were due to chance observation at

$$
\text { Age: } 18 \text { months Glucose: } 1 \mathrm{~g} / \mathrm{kg} \text { I.P. }
$$
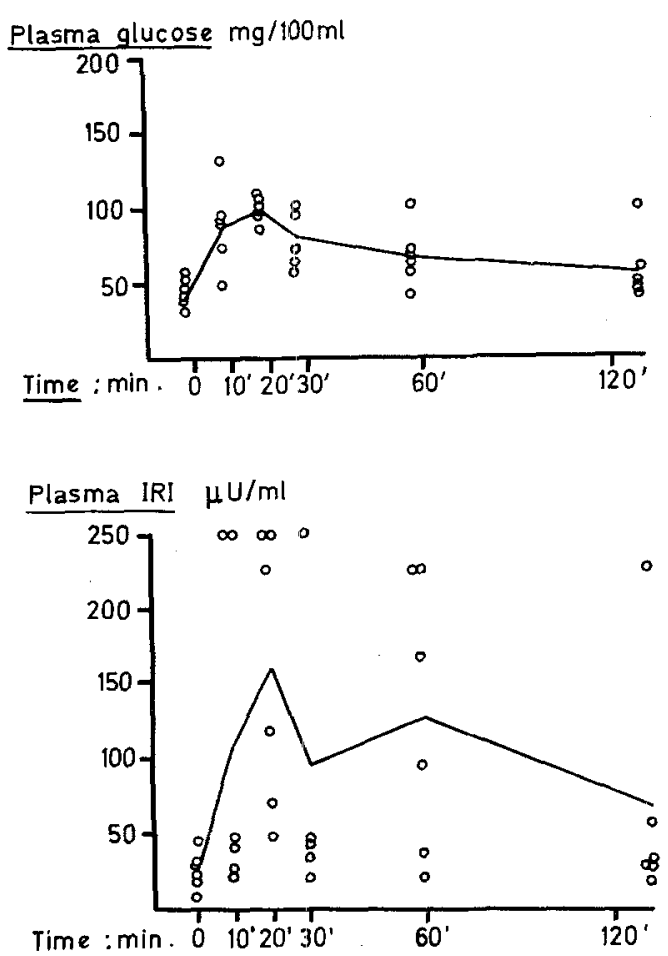

Fig. 5. Plasma glucose $(\mathrm{mg} / 100 \mathrm{ml}$, top panel) and plasma IRI concentrations ( $\mu \mathrm{U} / \mathrm{ml}$, bottom panel) of 18 months old normoglycemic spiny mice after the intraperitoneal injection of glucose $(1 \mathrm{~g} / \mathrm{kg}$ body weight $)$. Circles represent individual values. For details see text

a given time, groups of young (1 to 2 months old) and older (18 months old) animals were subjected to glucose loading in order to measure plasma IRI concentrations in a situation where it could be assumed that their 
pancreases were exposed to comparable degrees of stimulation. The results are shown in Figs. 4 and 5. In the young animals, both fasting and peak plasma glucose concentrations were higher and the peak concentration was reached earlier than in the older age group. Plasma insulin concentrations were again very variable in both groups. The majority of high values was encountered in anials killed shortly after the injection of glucose. In spite of this, no significant correlation could be established between plasma glucose and plasma insulin concentrations at any time during the tests. However, as already suggested by the experiment in fed animals (Fig. 3), it was found (Fig. 6) that in the older age groups (dots), the animals with high insulin concentrations at the time of peak glucose concentration were significantly heavier than those in which the lower values were measured. This relationship did not hold for young animals (triangles) although their peak insulin concentrations were comparable to those measured in the older age group. As indicated in Fig. 7, plasma IRI concentrations of the older animals appeared to increase with pancreatic insulin content when animals killed 10 and 20 min after glucose injection were taken into consideration. How ever, this relationship held only over a narrow range of pancreatic insulin content and notable exceptions were observed, in that only two of the four animals with the highest pancreatic insulin content were in the group with the highest plasma insulin concentrations.

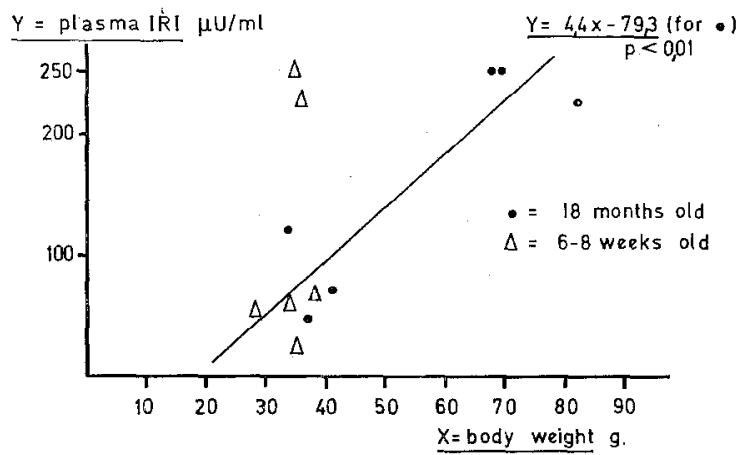

Fig. 6. Correlation between plasma IRI concentration $(\mu \mathrm{U} / \mathrm{ml})$ and body weight $(g)$ of the 6 to 8 weeks old (triangles) and 18 months old (dots) animals represented in Figs. 4 and 5 at the time of the peak plasma glucose concentration after IP glucose injection. The regression line was calculated from the values for 18 months old animals (dots)

\section{B. Electron Microscopic Studies}

Characteristically, the B-cells showed a high degree of granulation although a few scarcely granulated cells, randomly scattered through the islets, were encountered. In the vast majority of islets, the pale granules prevailed over the dense ones. This relative quantitative distribution of the two types of granules is well reflected by Fig. 8. While the core of the dense granules was of variable shape and surrounded by a large halo separating it from the limiting membrane, the pale material was either in close contact with the membrane or separated from it by a narrow space (Fig. 9). The granules showed a tendency to fusion and confluence (Figs. 8, 8a, 9).

Apart from the exception to be discussed below, we were unable to detect morphological evidence for enhanced insulin release in the B-cells of animals previously injected with glucose. The only alterations observed in these cells concerned the Golgi complex, the cisternae of which were frequently seen to contain maturing secretory granules both of the dense and of the pale type (Figs. 10, 11).

Figs. 12-15 represent pictures observed in the islets of one exceptional animal out of approximately 200 studied so far. They show numerous images of discharge of secretory granules by way of emiocytosis.

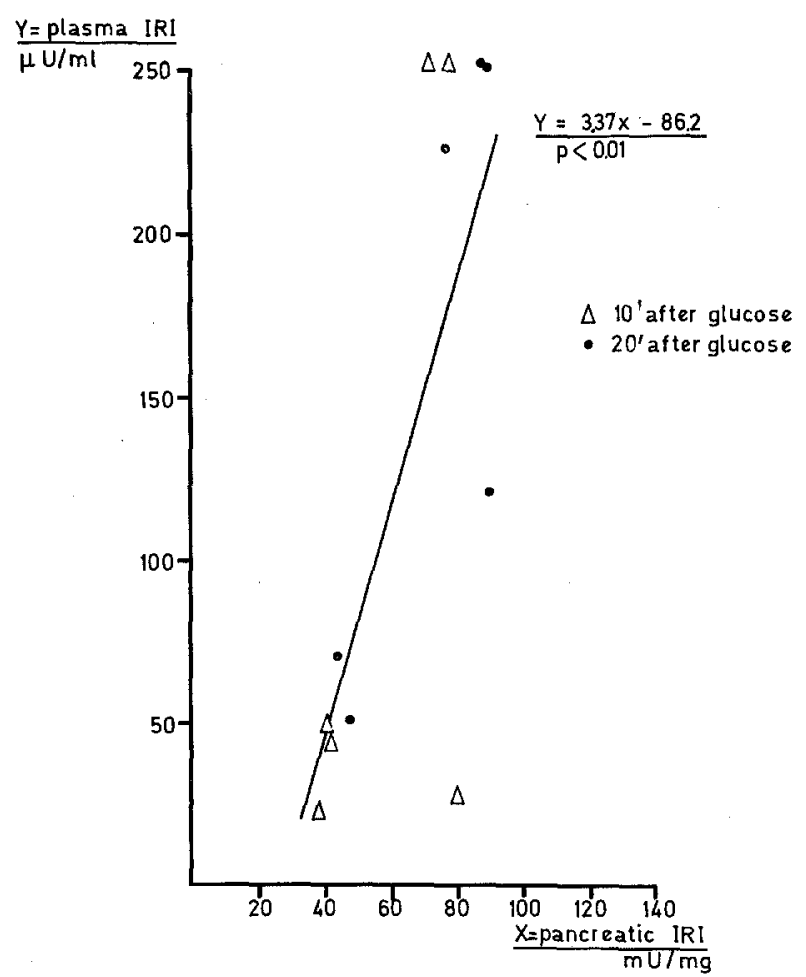

Fig. 7. Correlation between plasma IRI concentrations $(\mu \mathrm{U} / \mathrm{ml})$ and pancreatic IRI content $(\mathrm{mU} / \mathrm{mg})$ of the 18 months old glucose injected animals represented in. Fig. 5. Triangles denote results obtained with animals killed $10 \mathrm{~min}$ after glucose injection and dots those obtained with animals killed at $20 \mathrm{~min}$

The profile of the plasma membrane of these cells was characterized by the frequent occurrence of recesses of variable depth which contributed to the formation of numerous irregular, often clumsy, finger-like cytoplasmic projections which occupied the enlarged inter. cellular spaces.

Figs. 16 and 17 were obtained from animals killed after $6 \mathrm{~h}$ of continuous hyperglycemia. Despite this prolonged stimulation, the degree of granulation was comparable to that seen in fasted animals. Inciden- 
tally, it should be noted that Fig. 17 represents one of the rare B-cells which contained pale and dense granules in roughly equal proportions.

\section{Discussion}

Previously published results, primarily concerned with the definition of the diabetic state occurring in spiny mice $[8,9]$ and with the description of the morphological alterations of their B-cells characterising the evolution from the normal state to diabetic ketoacidosis $[5,6,16,8]$, have indicated that high circulating insulin concentrations, high pancreatic insulin content and congenital B-cell hyperplasia may occur genetically determined or environmentally induced characteristics of all animals of our colony or whether the few normoglycemic animals studied happened to be part of a population with an early or mild form of diabetes. Since our colony has grown considerably in the course of the last few years, the experiments reported here were devised to answer this question.

The results indicate that our colony of non-diabetic spiny mice comprises two populations which can be distinguished on the basis of the concentration of circulating immunoreactive insulin. In a majority of instances, both fasting plasma insulin concentrations and those measured after stimulation by feeding or glucose injection were low or within the normal range. The second group comprised animals in which the

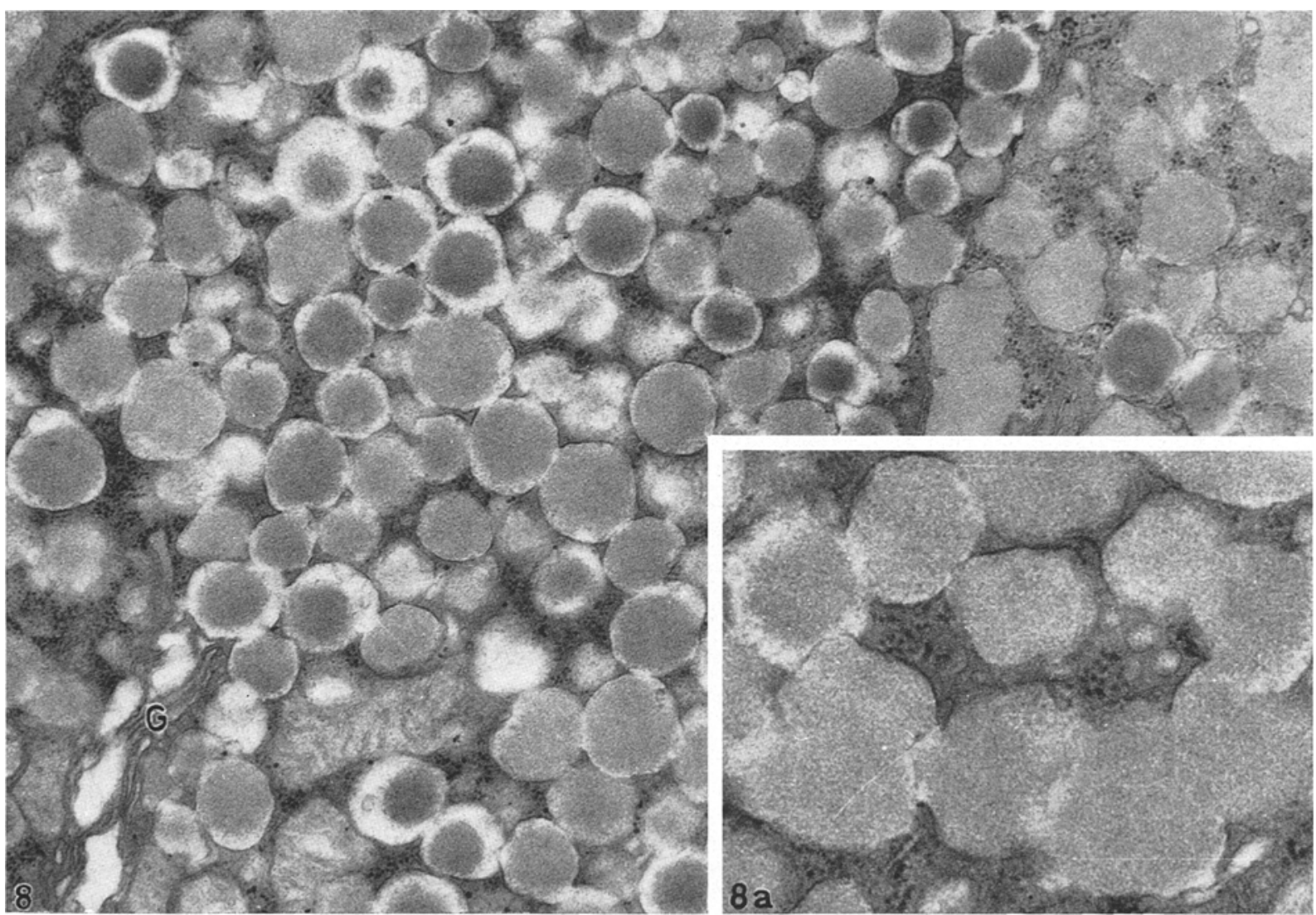

Fig. 8. Part of a hypergranulated B-cell of a 27 months old normoglycemic spiny mouse. The majority of the $\beta$-granules are of the pale type. Fusion and confluence between individual or several granules occur frequently. In the left lower corner, a Golgi complex (G) is seen $(23700 \times)$. The insert (Fig. 8a) shows fusion and confluence between several adjacent pale $\beta$-granules $(52000 \times)$

not only during the early phase of diabetes but also in what seemed to be "normal" animals $[6,8,9]$. However, the number of non-diabetic animals included in these experiments was very small since the necessity to maintain adequate breeding stocks limited the number of animals available for experimental use. It was therefore impossible to state with certainty whether hyperinsulinemia and islet hyperplasia were plasma IRI was high relative to the concentration of plasma glucose. While it is recognized that our inability to perform sequential measurements of plasma insulin in the same animal under varying conditions represents a serious limitation to the interpretation of the individual data, the repeated observation of similar degrees of variability of plasma IRI concentrations under conditions of fasting, feeding and glucose load- 
ing, the latter resulting in the simultaneous occurrence of comparable degrees of hyperglycemia, makes it unlikely that the distribution pattern of insulin concentrations observed resulted solely from the fact that the measurements represent a static assessment of a fluctuating process.

Since comparable degrees of hyperinsulinemia occurred in young and adult animals, the finding that plasma insulin concentrations in the fed state or after glucose injection correlated with body weight in adult but not in young animals indicates that hyperinsulinemia may be the cause rather than the consequence of accelerated weight gain. The age-dependent progressive increase of pancreatic IRI content and concentration and their relative independence of the concentration of circulating insulin - (only in adult, glucoseinjected animals did the two values correlate) - suggests that B-cell hyperplasia may occur independently tion of an occasional islet, the B-cells of which contained comparable numbers of pale and dense granules, the $\beta$-granules were predominantly of the pale type and showed varying degrees of fusion and confluence. These pictures were comparable to those we have previously described in spiny mice with intermittent glycosuria [16]. To the knowledge of the authors, similar degrees of predominance of pale over dense granules have only been described in newborn rabbits [21]. However, in these animals, confluence of pale granules does not seem to occur and the number of dense granules increases with age so that B-cells of adult rabbits contain roughly equal proportions of dense and of pale secretory granules. Thus, both the predominance of pale granules in an overwhelming majority of islets throughout life and their tendency to confluence appear to be characteristic features of the B-cells of the spiny mouse.

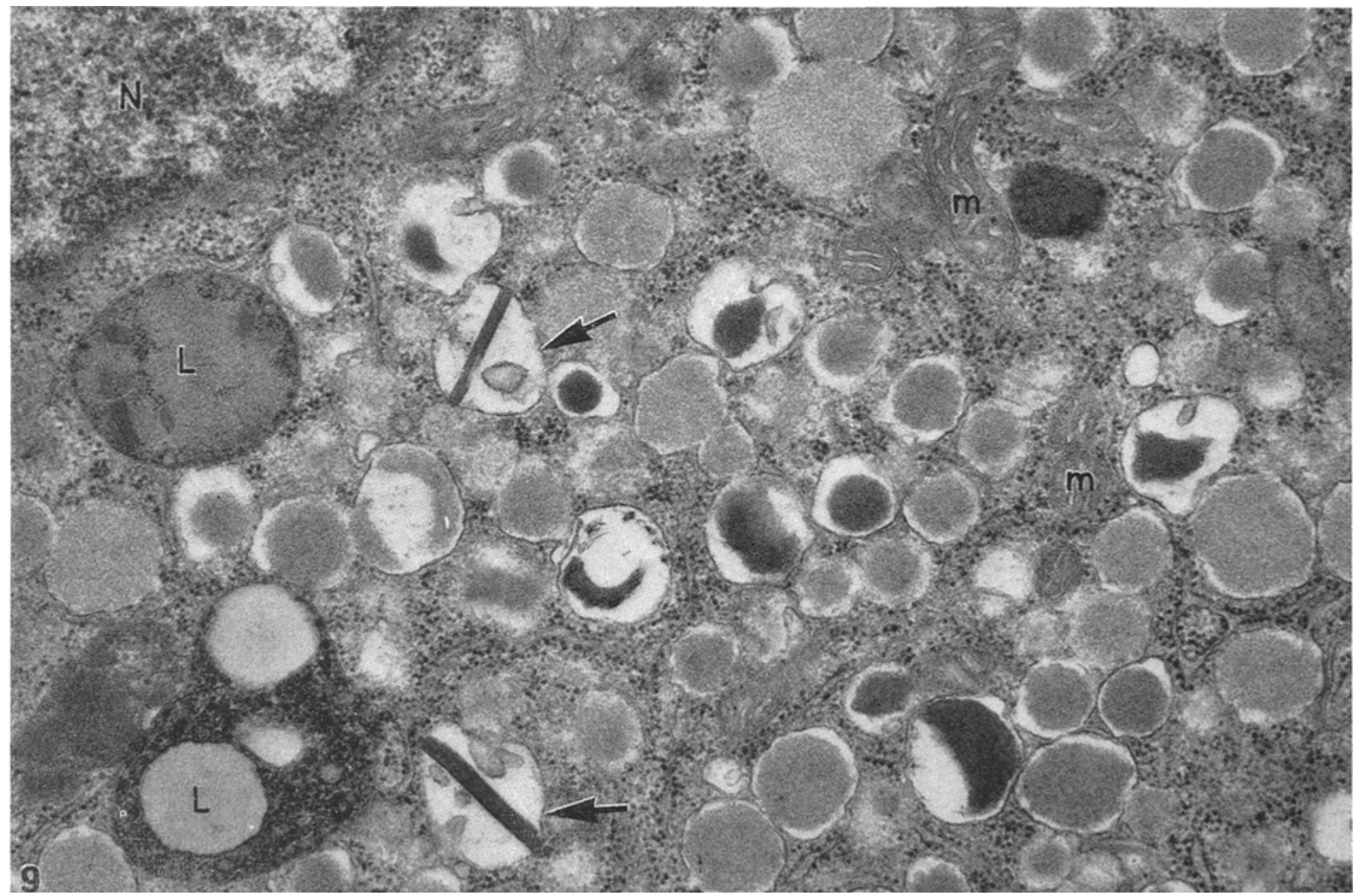

Fig. 9. Part of a B-cell of a 28 months old normoglycemic spiny mouse showing pale and dense $\beta$-granules. Two of the latter (arrows) are of rectangular shape. $\mathrm{m}=$ mitochondrion, $\mathrm{L}=$ lysosome, $\mathrm{N}=$ nucleus, $(25800 \times)$

of peripheral insulin concentration and of insulin demand.

The ultrastructural aspect of the islets of the close to 200 normoglycemic animals thus far examined was strikingly uniform in that the B-cells showed an unusual degree of granulation. Scarcely granulated cells exhibiting signs of protein synthesis and of granule formation were seen but very rarely. With the excep-
Morphological examination does not allow for the identification of the structural characteristics responsible for the electron density of secretory granules. It is therefore impossible to decide whether the pale aspect of the majority of granules of spiny mice is due to the structure or to the state of aggregation of the storage-form of insulin or to a characteristic feature of the membrane surrounding it. The frequent fusion 


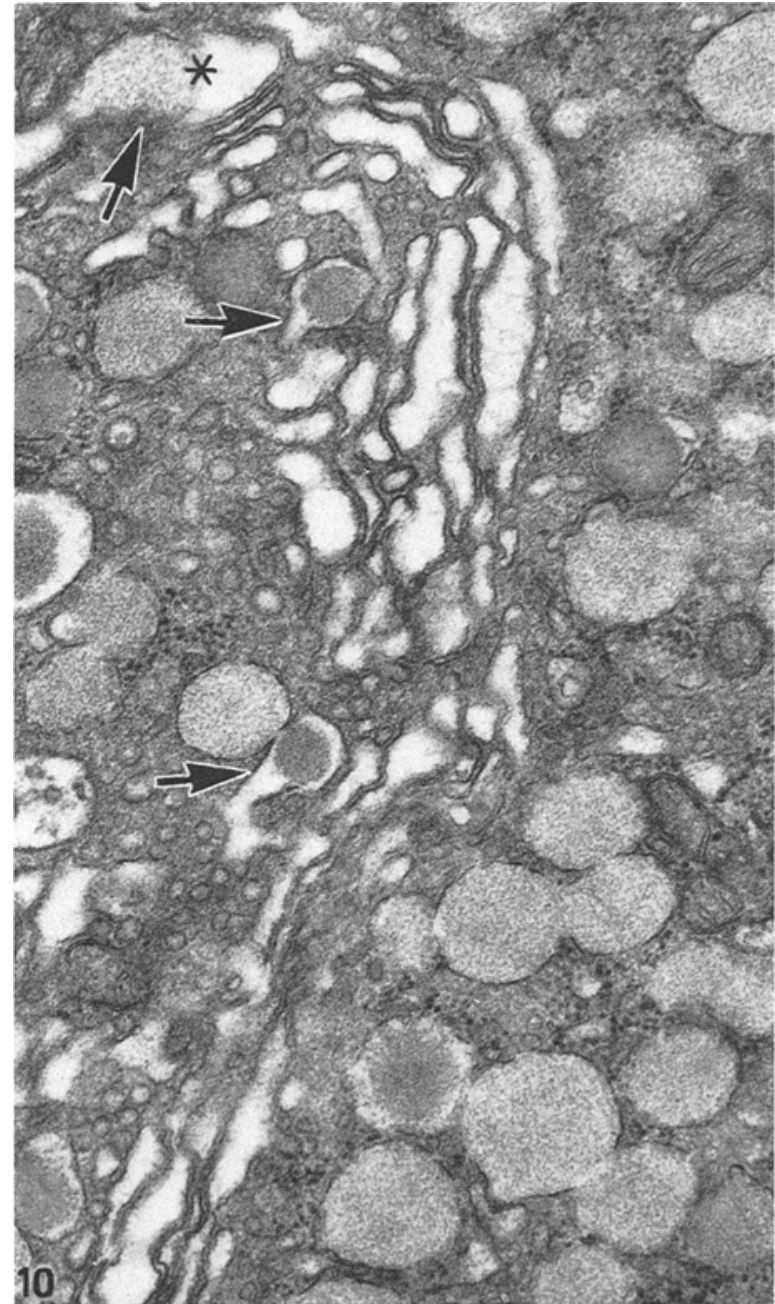

Fig. 10. Part of a B-cell of a $1 \frac{1}{2}$ months old spiny mouse killed $1 \mathrm{~h}$ after the IP injection of glucose $(1 \mathrm{~g} / \mathrm{kg})$. Plasma glucose at time of killing: $190 \mathrm{mg} / 100 \mathrm{ml}$, plasma IRI: $10 \mu \mathrm{U} / \mathrm{ml}$. Several cisternae (arrows) of the enlarged Golgi complex contain maturing seeretory granules. The electron-density of one of them $\left(^{*}\right)$ is similar to that of neigh bouring pale granules, $(27000 \times)$

between pale secretory granules which we have thus far observed only in B-cells of spiny mice, deserves comment. The possibility that excessive fragility of the granule membrane might be responsible for this phenomenon cannot be excluded a priori. Indeed, the state of preservation of other cell organelles of the same $B$ cells appears to rule out the possibility of a fixation artefact. However, it should be stressed that the degree of granulation of B-cells of spiny mice is such that the $\beta$-granules are in close contact with each other. This unusual feature which is quite characteristic for spiny mice, may in itself be responsible for the occurrence of fusion between immediately adjacent granules

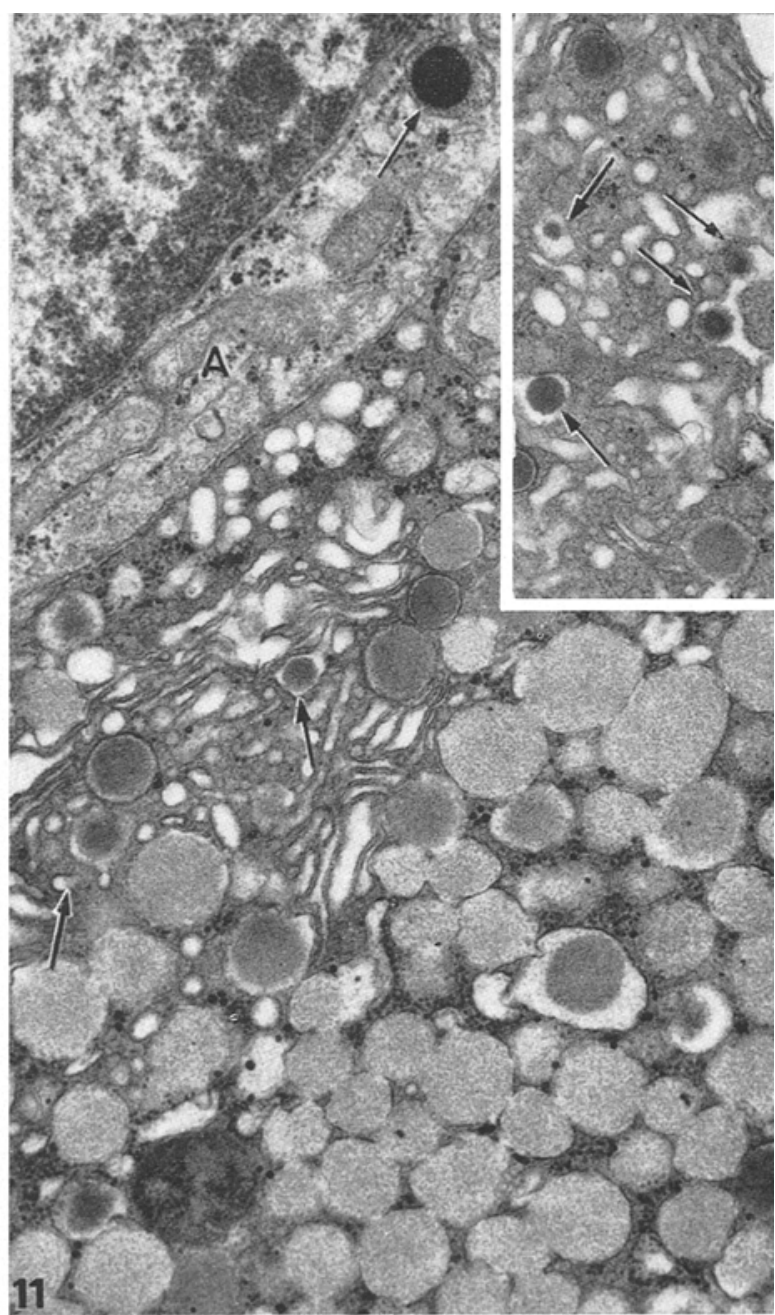

Fig. 11. $11 / 2$ months old spiny mouse killed $1 \mathrm{~h}$ after the IP injection of glucose $(1 \mathrm{~g} / \mathrm{kg})$. Plasma glucose at time of killing $408 \mathrm{mg} / 100 \mathrm{ml}$, plasma. IRI $15 \mu \mathrm{U} / \mathrm{ml}$. Part of a B-cell filled with pale secretory granules. The cisternae (arrows) of the Golgi complex show evidence of packaging of secretory granules. In the upper left corner, part of an $A$-cell (A) with a characteristic $\alpha$-granule (arrow) is seen, $(21000 \times)$. In the insert, several dense secretory granules undergoing maturation are shown (arrows), $(18000 \times)$

in vivo or for apparent fusion during the process of tissue preparation. Both mechanisms would allow for the explanation of both, the occurrence of granulefusion and its apparent specificity for spiny mice without the need for the assumption of a structural abnormality.

The features most consistently observed in B-cells of animals previously injected with glucose and of those exposed to continuous hyperglycemia for $6 \mathrm{~h}$ were the persistence of a high degree of granulation, the absence of morphological signs indicative of enhanced insulin release and the frequency with which already well granulated cells exhibited evidence sug. 

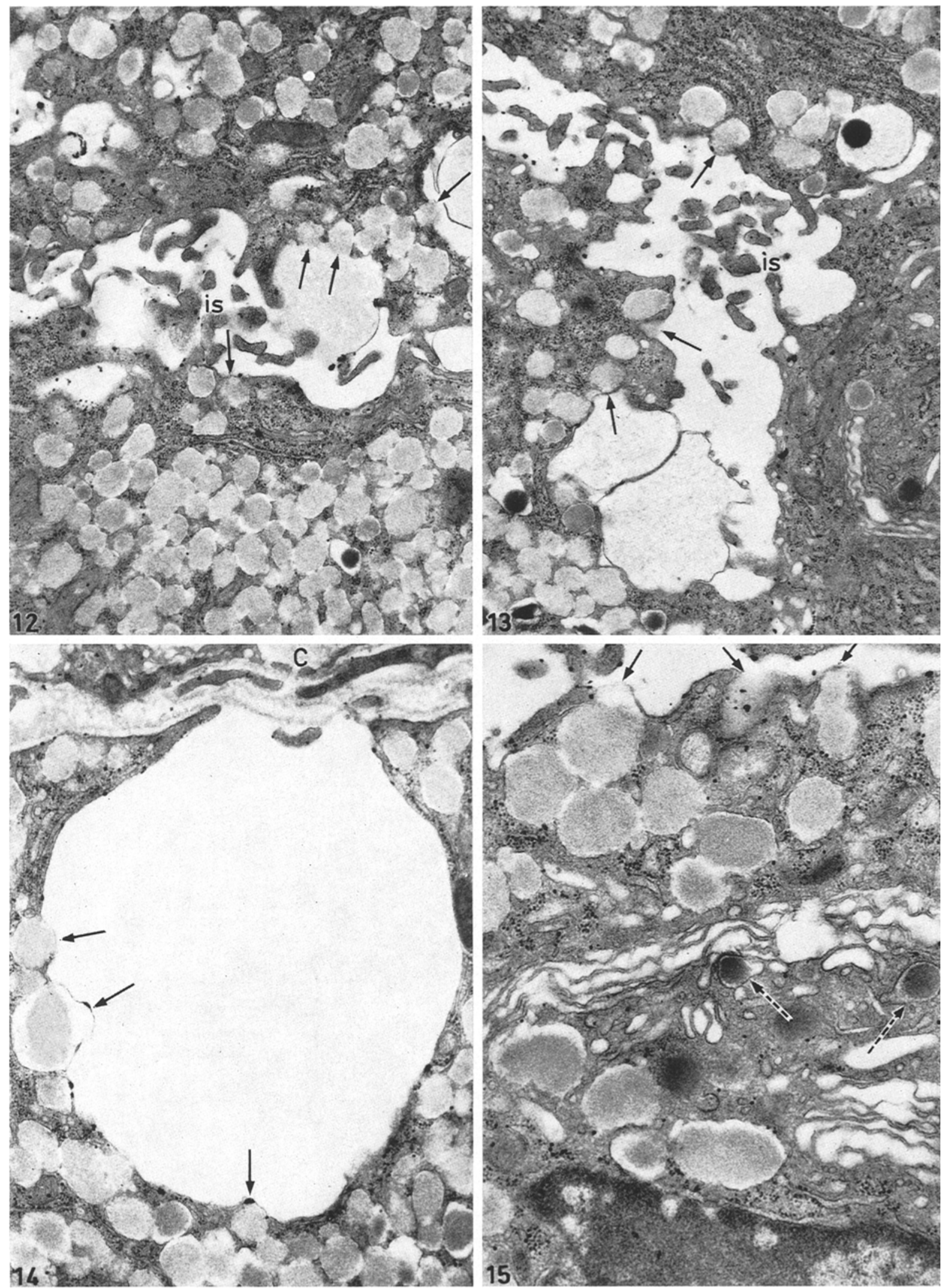
Table 2. Ratio plasma IRI ( $\mu U / m l) /$ pancreas IRI ( $m U / m g)$ of spiny mice and other strains of mice a

$\begin{array}{llll}\text { 1. Spiny mice } & & \\ 36 \text { months old, fasted } & (n=9) & 0.4 \pm 0.08 \\ 36 \text { months old, fod } & (n=6) & 1.4 \pm 0.44 \\ \text { Low plasma IRI: } & 1-6 \text { months old, fed } & (n=12) & 1.1 \pm 0.62 \\ & 12 \text { months old, GTTb } & (n=6) & 0.9 \pm 0.18 \\ \text { High plasma IRI: } 1-6 \text { months old, fed } & (n=8) & 4.8 \pm 0.68 \\ & 18 \text { months old, GTT } & (n=6) & 2.8 \pm 0.31\end{array}$

2. Other strains of mice

A normal: Swiss mice fasted

$o b$ mice fasted

Swiss mice fed

$o b$ mice fed $\quad 26$

B obese-hyperglycemic:

$\begin{array}{lr}\text { Goldthioglucose-obese fasted } & 9 \\ \text { Goldthioglucose-obese fed } & 128 \\ \text { abob 5 weeks old, fed } & 279 \\ \text { obob } 8 \text { weeks old, fed } & 119\end{array}$

a Values indicated for spiny mice $=$ means of individual ratios + SEM. Values indicated for other strains were calculated from (9). Individual ratios could not be calculated since IRI was measured on pools of sera. For explanation see text.

b GTT = animals injected with glucose.

gestive of further insulin production, in that the cisternae of their Golgi complex contained numerous maturing granules. Although all animals subjected to the 2 types of glucose loading were carefully examined, emiocytosis was seen in only one of them, the B-cells of which incidentally also showed appreciable degrees of degranulation.

In general, the ultrastructural aspect of the B-cells suggests that they contain large amounts of insulin stored in pale granules irrespective of the degree or the duration of secretory stimulation and that this large pool of granular insulin is relatively inaccessible. In addition, the cells appear to respond to hyperglycemic stimulation with insulin synthesis and granule formation regardless of the degree of granulation they have already attained or which they maintain.

These studies have not allowed for the detection of a morphological basis for the variability of plasma insulin concentrations observed in the same animals. This supports the previously elaborated contention that the variations of peripheral insulin concentrations may be independent of pancreatic insulin content.

Figs. 12-15. 11/2 months old spiny mouse $2 \mathrm{~h}$ after the IP injection of glucose $(1 \mathrm{~g} / \mathrm{kg})$. Plasma glucose at time of killing: $119 \mathrm{mg} / 100 \mathrm{ml}$, plasma IRI $96 \mu \mathrm{U} / \mathrm{ml}$

Fig. 12 and 13 show numerous emiocytotic images along the plasma membrane (arrows). The intercellular space (is) is enlarged and contains irregular, finger-like cytoplasmic processes $(15000 \times)$

Fig. 14 shows part of a B-cell adjacent to a capillary (C). A deep recess into which granules appear to be discharging (arrows) is shown $(17000 \times$ )

On Fig. 15, arrows indicate granules apparently involved in different stages of the sequence leading to emiocytosis. Two maturing secretory granules are seen in the cisternae of the Golgi complex (broken arrows), $(22000 \times)$
Indeed, both the metabolic characteristics of our animals and the morphological aspect of their B-cells may be considered to be consistent with the hypothesis that a defect of the B-cells may interfer with insulin secretion, thereby leading to a progressive accumulation of relatively inaccessible pancreatic insulin stores.

This hypothesis is indirectly supported by three further lines of evidence: Firstly, studies of insulin release in vitro have indicated that the response of pancreatic tissue of spiny mice to secretory stimuli may be sluggish [6] and unpublished data). Secondly, we have recently observed phenomena indicative of the occurrence of intracellular disposal "of secretory granules by granulolysis in B-cells of spiny mice [1]. The relevance of this observation for the hypothesis under consideration emanates from the general acceptance of the phenomenon of granulolysis as a morphological expression of the destruction of unneeded secretory granules by endocrine cells. It occurs both after the apparent cessation of the need for a hormone (for glucagon in diabetes, for prolactin upon termination of lactation), and in B-cells after the inhibition of insulin release in vivo by diazoxide $[14,15,19,3]$. Thirdly, the comparison of plasma insulin concentrations with pancreatic insulin content may represent a means for the assessment of the relative sensitivity of the B-cells to secretory stimulation in vivo [9]. Accordingly, the ratio of plasma IRI concentration over pancreatic insulin content was calculated for the animals used in experiments reported here and compared to those calculated from experiments performed earlier with normal Swiss mice, goldthioglucose-obese Swiss mice and with obob mice. The results are summarized in Table 2 and indicate that, relative to pancreatic insulin content, plasma insulin concentrations even of those spiny mice which had the highest values 

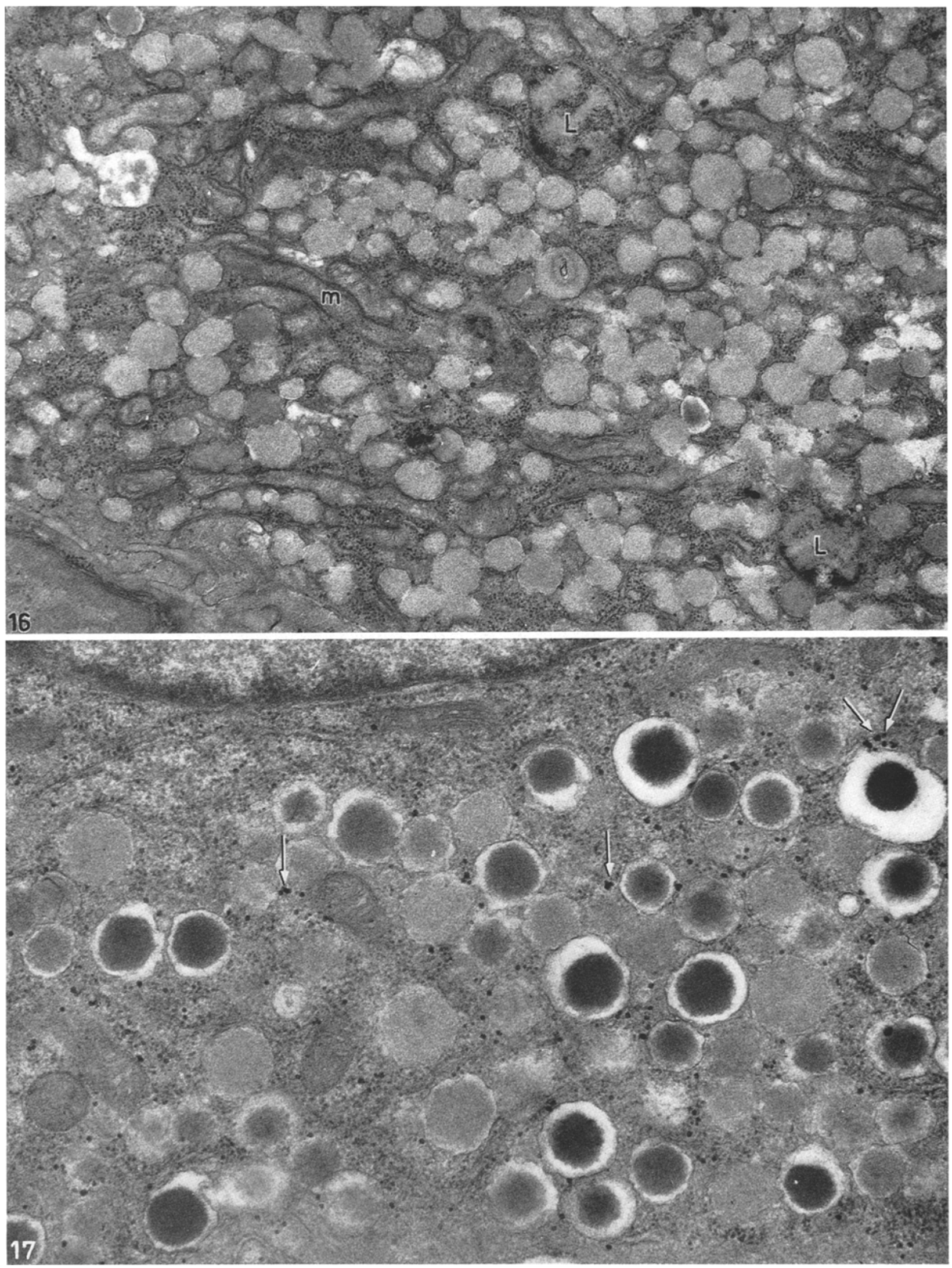
in response to feeding or to the injection of glucse, were lower than those measured in any other type of mouse studied, fasted or fed, normal or obese-hyperglycemic.

The nature of the postulated defect responsible for the impairment of insulin secretion remains unknown It might involve the granule membrane, the granular form of insulin or structures more directly involved in the release of normally synthesized and stored insulin. Currently available experimental techniques do not allow for testing of the first possibility. With respect to the second point, namely the nature of the insulin stored in the pancreas of sping mice, a preliminary comparison of its biological potency with its immunoreactivity has failed to show any significant difference between Acomys insulin and crystalline rat or porcine insulins (Fig. 18). However, dise gel electrophoresis of

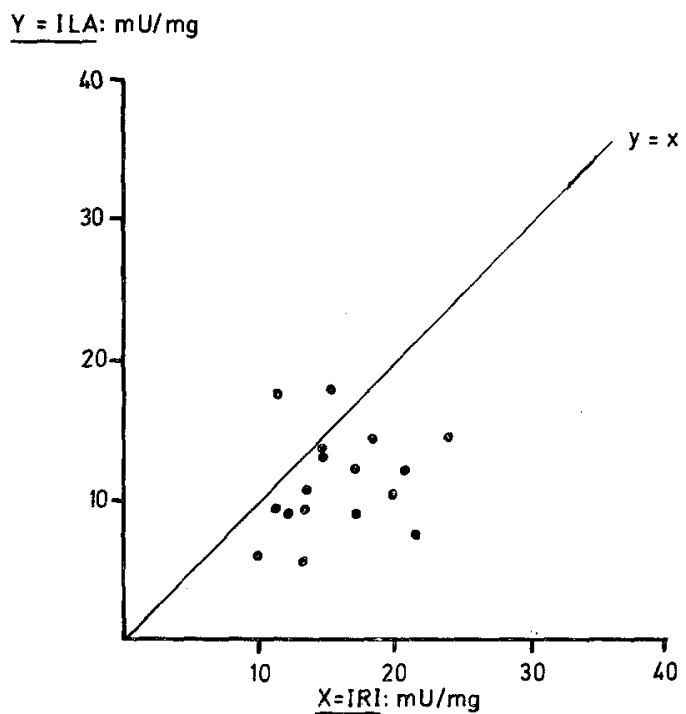

Fig. 18. Scattergram of individual measurements of ILA (rat adipose tissue, ordinate) and IRI (abscissa) performed on pancreatic extracts of 17 normoglycemic spiny mice (6 to 8 weeks old). The line $\mathrm{y}=\mathrm{x}$ represents the "ideal" regression line indicating identity of values for ILA and IRI

partially purified pancreatic extracts has indicated that, similar to what is known for the rat, the pancreas of spiny mice may contain two structurally distinct insulins (Fig. 19). Only further analysis of the structure, the biological poteney and the immunological properties of these two insulins will allow for an

Fig. 16. 18 months old spiny mouse killed after $6 \mathrm{~h}$ of continuous hyperglycemia. Plasma glucose at time of killing: $303 \mathrm{mg} / 100 \mathrm{ml}$, plasma IRI $35 \mu \mathrm{U} / \mathrm{ml}$. Part of a $\mathrm{B}$-cell containing numerous pale secretory granules. $\mathrm{m}=$ mitochondria, $\mathrm{L}=$ lysosome, $(19500 \times)$

Fig. 17. Same animal as Fig. 16. Part of a B-cell containing comparable numbers of pale and dense secretory granules. Small, dense particles scattered throughout the cytoplasm probably represent glycogen in its monoparticulate form (arrows) $(28500 \times)$ appraisal of their eventual importance for the anomalies observed in the pancreas of spiny mice. The functional integrity, in B-cells of spiny mice, of the mechanisms involved in the release of insulin in response to secretory stimulation cannot be assessed on the basis of currently available data. However, in view of the apparent importance of the autonomous nervous system for the regulation of insulin release [17, 2], our consistent inability to detect autonomous nerve endings in the islets of spiny mice may be of importance.

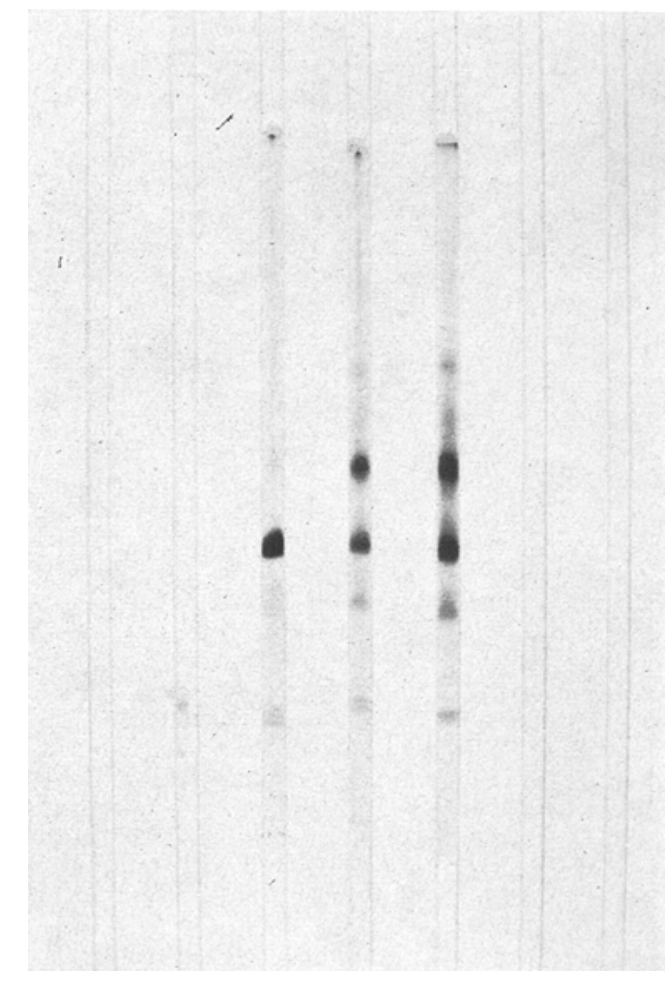

Fig. 19. Porcine (left) and spiny mouse (2 concentrations) insulin profiles as obtained from disc gel electrophoresis on polyacrylamide $(15 \%)$. L. Balant, I.M. Burr, W. Stauffacher, unpublished observation

Whatever the nature of the defect of the B-cells of spiny mice may be, the hypothesis best fitting both the biological data and the morphologic features described here implies that the B-cells of spiny mice contain two compartments of insulin, one of which is very small, has a rapid turnover, and is accessible to secretory stimulation. The other, however, accounts for most of the insulin contained in the B-cells, is not accessible to secretory stimulation and increases progressively with age. The observation that evidence for insulin synthesis, namely granule formation by already well granulated B-cells, was the only morphological feature consistently encountered in islets of glucoseinjected animals may reflect the response of the small releasable pool of insulin to secretory stimulation. In addition, our inability to distinguish the small releasable pool of insulin from that retained in the pan- 
creas may explain the relative lack of correlation between pancreatic insulin content and plasma insulin concentrations.

Acknowledgements. The authors are indebted to Dr. J. Schlichtkrull, Novo Research Laboratories, Copenhagen, Denmark, for the purified rat insulin standard. The expert technical help of Mrs. Janine Bassi, Mrs. Marthe Sidler-Ansermet and of Miss Charlotte Hedinger is gratefully acknowledged.

\section{References}

1. Amherdt, M., Orci, L., Stauffacher, W., Renold, A.E. Rouiller, Ch.: Morphological evidence suggestive of an impairment of insulin secretion in vivo in normoglycemic spiny mice (Acomys Cahirinus). Proc. VII Int. Congr. Electron Microscopy, Grenoble 1970, in press.

2. Cerasi, E., Effendic, S., Luft, R.: Role of adrenergic receptors in glucose-induced insulin secretion in man. Lancet 1969 II, 301-302.

3. Creutzfeldt, W., Creutzfeldt, C., Frerichs, H., Perings, E., Sickinger, K.: The morphological substrate of the inhibition of insulin secretion by Diazoxide. Horm. Metab. Res. 1, 53-64 (1969).

4. Froesch, E.R., Bürgi, H., Ramseier, E.B., Bally, P., Labhart, A.: Antibody suppressible and non-suppressible insulin like activities in human serum and their physiological significance. An insulin assay with adipose tissue of increased precision and specificity. J. clin. Invest. 42, 1816-1834 (1963).

5. Gonet, A.E., Mougin, J., Renold, A.E.: Hyperplasia and hypertrophy of the islets of Langerhans, obesity and diabetes mellitus in the mouse Acomys Dimidiatus. Acta endocr. Suppl. 100, 135 (1965).

6. - Stauffacher, W., Pictet, R., Renold, A. E.: Obesity and diabetes mellitus with striking: congenital hyperplasia of the islets of Langerhans in Spiny Mice (Acomys Cahirinus). Diabetologia 1, 162-171 (1965).

7. Hales, C.N., Randle, P.J.: Immunoassay of insulin with insulin antibody precipitate. Biochem. J. 88, $127-146$ (1963).

8. Junod, A., Orci, L., Renold, A. E.: Lésions morphologiques et physiologiques dans le syndrome complexe des souris à piquants (Acomys Cahirinus). In: Journées annuelles de diabétologie de l'Hôtel-Dieu, Paris, p. 31-39. Paris: Ed. Médicales Flammarion 1968

9. - Letarte, J., Lambert, A. E., Stauffacher, W.: Studies in Spiny Mice (Acomys Cahirinus): Metabolic state and pancreatic insulin release in vitro. Horm. Metab. Res. 1, 45-52 (1969).
10. Karnovsky, M.J.: Simple methods for "staining with load" at high $\mathrm{pH}$ in electron microscopy. J. biophys. biochem. Cytol. 11, 729-732 (1961).

11. Luft, J.H.: Improvements in Epoxy resin embedding methods. J. biophys. biochem. Cytol. 9, 409-419 (1961).

12. Michod, J., Frei, J.: Méthode rapide et spécifique pour le dosage de la glycémie par l'O-toluidine pour les urgences. Bull. Soc. suisse chim. clin. 7, 54-58 (1963).

13. Millonig, G.: Advantages of a phosphate buffer for $\mathrm{OsO}_{4}$ solutions in fixation. J. appl. Physiol, 32, 1637 (1961).

14. Orci, L., Junod, A., Renold, A. E., Rouiller, Ch. : Granulolysis in A-cells of endocrine pancreas in spontaneous and experimental diabetes in animals. J. cell. Biol. $\mathbf{3 8}$, $462-466$ (1968).

15. - Stauffacher, W., Dulin, W.E., Renold, A.E.: Ultrastructural changes in A-cells exposed to diabetio hyperglycemia. Observations made on pancreas of chinese hamsters. Diabetologia, this issue.

16. Pictet, R., Orci, L., Gonet, A.E., Rouiller, Ch., Renold, A. E. : Ultrastructural studios of the hyperplastic islets of Langerhans of Spiny Mice (Acomys Cabirinus) before and during the development of hyperglycemia. Diabetologia 3, 188-211 (1967).

17. Porte, D., Jr., Graber, A.L., Kuzuya, T., Williams, R. H.: The effect of epinephrine on immunoreactive insulin levels in man. J. clin. Invest. 45, 228-236 (1966).

18. Scott, D.A., Fisher, A.M.: The insulin and zine content of normal and diabetic pancreas. J. clin. Invest. 17, $725-728$ (1938).

19. Smith, R.E., Farquhar, M.G.: Lysosomal function in the regulation of the secretory process in cells of the anterior pituitary gland. J. Cell Biol. 31, 319-347 (1966).

20. Stauffacher, W., Lambert, A.E., Vechio, D., Renold, A.E.: Measurements of insulin activities in pancreas and serum of mice with spontaneous ("obese" and "New Zealand obese") and induced (goldthioglucose) obesity and hyperglycemia with considerations on the pathogenesis of the spontaneous syndrome. Diabetologia 3, 230-237 (1967).

21. Wellmann, K.F., Volk, B.W., Lazarus, S.S., Brancato, P.: Pancreatic B-cell morphology and insulin content of normal and alloxan-diabetic rabbits and their offspring. Diabetes 18, 138-145 (1969).

Dr. W. Stauffacher Institut de Biochimie Clinique Sentier de la Roseraie CH-1211 Genève 4 